\section{Lite spiselig}

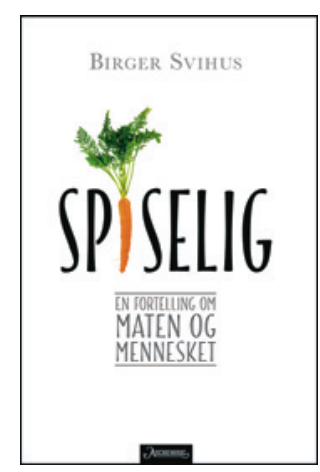

Spiselig henvender seg hovedsakelig til overvektige og lite fysisk aktive - med andre ord en ganske stor leserskare. Den omhandler hvordan matvalg påvirker miljøet og helsen, og forfatteren beskriver utfordringen vi har med å mette en raskt voksende befolkning og gir kostråd som skal ivareta bærekraft og helse. Budskapet spriker imidlertid, slik at $i$ alle fall denne leseren sitter forvirret igjen.

Innledningsvis er forfatteren tydelig på at et plantebasert kosthold, kjøtt fra beitedyr og kortreist mat er mest bærekraftig, og at hverken bonden, jorden, plantene eller dyrene bør tynes til det ytterste for å skaffe nok og billig mat. Det er det lett å holde med ham i.

Forfatteren mener at det industrielle landbrukets metoder er overveiende positive, og avskriver økologisk landbruk uten å forklare hvorfor. Tar FN feil i sin rapport fra 2013 når de konkluderer med at verden bør legge om til økologisk jordbruk omgående, hvis en raskt voksende befolkning mettes på bærekraftig vis?

Det redegjøres godt for fysiologiske mekanismer bak smak, metthet, kaloriforbruk og vekt. Leseren kan dessverre villedes til å tro at moderne teknologi er forbeholdt et industrialisert jordbruk. Fremstillingen fortsetter med å bli noe ensidig når mer kunstgjødsel og sprøytemidler beskrives som en forutsetning for økte avlinger. Hvilke rapporter ligger til grunn?

Verdensrekorden på risavling per i dag innehas av den unge indiske økobonden Sumant Kumar. En av årsakene til imponerende rekordavlinger fri for kunstgjødsel og sprøyting er modernisering og nytenkning om plantemetoder for ris. Forfatteren kaller økobonden for «øko-Blitzer» og den økobevisste forbruker for villedet. Er Stortinget også villedet til sitt mål om 15 prosent forbruk av økologisk mat innen 2020 ?

Avslutningsvis oppfordres leseren til å spise kortreist mat og generelt velge et mer plantebasert kosthold og kjøtt fra beitedyr. Unngå siktet hvete, hvit ris, sukker og planteoljer. Gode råd som nok kan bedre både vekt og helse om du følger dem. Kabalen går imidlertid ikke opp, idet du da må handle lokalt av nettopp «øko-Blitzeren» for eksempel i jakten på kjøtt fra beitedyr.

Det er overraskende at et manus som tilsynelatende trakasserer produsenter og forbrukere av økologisk mat og lovpriser matkjemi og genetisk modifiserte organismer (GMO), bagatelliserer det industrielle jordbrukets konsekvenser. Det er ikke med på å skape en sunn offentlig debatt.

\section{Berit Nordstrand}

Lege, forfatter og foredragsholder

Trondheim

\section{Glimrende bok om EKG og arytmier}

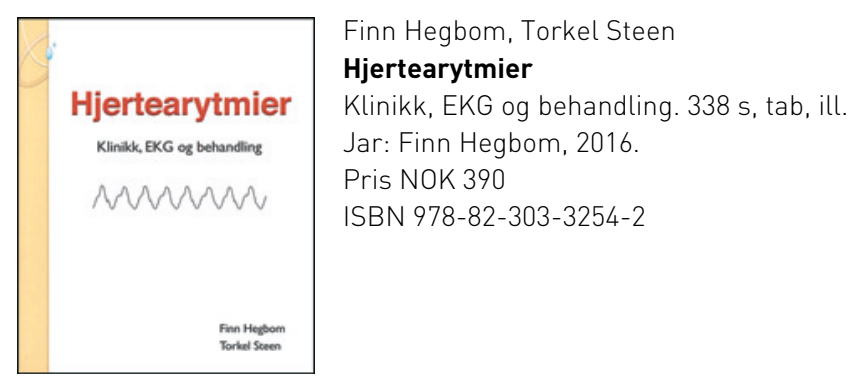

Dette er en perle om hjertearytmier! Begge forfatterne har lang klinisk erfaring fra Oslo universitetssykehus, og sammen med syv kolleger har de på 335 sider maktet å samle en imponerende mengde fakta og gode kliniske anbefalinger om EKG-analyser og behandling av arytmier.

Utgivelsen er i et hendig format som lett passer i lommen på en legefrakk. Den inneholder gode og illustrerende figurer som $i$ hovedsak er hentet fra forfatternes egne kliniske hverdager. Boken dekker det meste av EKG-analyse, arytmidiagnostikk og behandling ved arytmier hos idrettsutøvere, synkope, genetiske arytmisyndromer og plutselig død. I tillegg tar forfatterne for seg arytmier på intensiv avdelinger, arytmier hos gravide og hos pasienter med medfødte hjertefeil, og pasienter med ablasjon.

For spesielt interesserte er det flere nyttige tillegg om tolkning av mutasjoner, og ulike kriterier (Arytmogen kardiomyopati i høyre ventrikkel og ICD-implantasjon) samt beskrivende teknikk for pacemakerimplantasjon og gode råd for programmering og finjustering av pacemakere.

Hjertearytmier vil være til stor generell nytte for medisinstudenter, leger i spesialisering innen indremedisin og hjertesykdommer, samt kardiologer. Den vil dessuten kunne bidra til at mange kardiologer får noen aha-opplevelser og får med seg flere nyttige kliniske tips i hverdagen. Den kan leses fra perm til perm for de som ønsker en grundig og generell oppfriskning, men egner seg også utmerket som oppslagsverk - for eksempel når man lurer på hvor i hjertet en ventrikulær ekstrasystole kommer fra, eller hvordan man skal tolke en vrien takyarytmi.

\section{Per Anton Sirnes}

Spesialist hjertesykdommer, Østlandske Hjertesenter Moss 